\title{
TELEMEDICINE FOR SELF-MANAGEMENT OF TYPE 2 DIABETES: A LITERATURE REVIEW
}

\section{Bunjamin Dante Masepia*, Atyanti Isworo}

Department of Nursing, Faculty of Health Sciences, Universitas Jenderal Soedirman, Indonesia

\section{Article Information}

Received: 1 October 2020

Revised: 9 December 2020

Accepted: 21 March 2021

\section{*Corresponding Author}

Bunjamin Dante Masepia

bunjamindm@gmail.com

\section{DOI}

10.20884/1.jks.2021.16.1.1548

\begin{abstract}
The COVID-19 pandemic is an obstacle that prevents people living with type 2 diabetes from visiting primary health services. Telemedicine is a virtual health service that helps caregivers and clients to meet virtually. Telemedicine is capable of assisting sufferers in the form of self-management. This study aims to determine the effect of telemedicine on self-management of type 2 diabetes patients. This study uses a literature review design. Primary studies to be included in this review were searched from Pubmed electronic database. The inclusion criteria of studies were: published in the last five years in English-language journals, used randomized control trial design, had population aged $>18$ years with type-2 diabetes, and used telemedicine. The exclusion criterion was comparing two or more telemedicine applications. A total of 11 studies was included in the review. Seven out of eleven studies showed a significant reduction in $\mathrm{HbA1C}$ in the intervention group than the control group. Another result is a change in diet by consuming more fruits and whole grains and increasing knowledge, skills, and ability to control blood sugar. This review concluded that telemedicine improves the self-management of type 2 diabetes patients. Health care professionals can use telemedicine as an alternative to enhance the selfmanagement of type 2 diabetes patients.
\end{abstract}

Keywords: HbA1c; self-management; telemedicine; type-2 diabetes

\section{INTRODUCTION}

The COVID-19 pandemic started in December 2019 in Wuhan, China. By early 2020 there had been an increase in cases of Coronavirus worldwide. According to WHO (2020), cases of the world's corona virus on June 22, 2020 amounted to $8,860,331$ cases and 465,740 of those people have died. Cases in Indonesia have continued to increase since March 2, 2020 until now, where there have been 45,891 cases and 2,465 deaths. Every citizen is encouraged to understand the ways of transmission and prevention of the corona virus.

The corona pandemic is one of the obstacles for sufferers of chronic diseases such as diabetes mellitus who need to go to health services regularly. A routine checkup is very important to help diabetics control their blood sugar and gain knowledge of a healthy lifestyle. According to Ghosh, Arora, Gupta, Anoop, and Misra (2020), the innovation to overcome these obstacles is to use technology to connect the doctor and healthcare to clients virtually, namely telemedicine.

According to International Diabetes Federation (2019), in 2019 Indonesia was ranked seventh in the world, with 10.7 million cases of diabetes. Most cases are type 2 diabetes. Type 2 diabetes mellitus sufferers usually do not need insulin injections in their treatment but take medications to improve insulin function. Some of the factors affecting patient self-management are knowledge, self-efficacy and social support (Malini, Yeni, Pratiwi and Lenggogeni, 2020).

Telemedicine can affect patient self-management. Some of the names of telemedicine applications for type 2 diabetes are Diabeo, Diabetes Pal, Blue Star and Bant2. The telemedicine applications provide information and discussions with the healthcare provider about care plans so it can increase the diabetic's knowledge and improve the behavior related to diabetes. For long term outcome, it is 
also expected that the metabolic response is also improved, which is proven by decreased $\mathrm{HbA1c}$ levels. Thus, the purpose of this review is to identify the effect of telemedicine on self-management of type 2 diabetics. Result of this review can provide information whether or not telemedicine is a breakthrough for the self-management of type 2 diabetes, particulary during the COVID-19 pandemic.

\section{METHOD}

\section{Study Design}

This study used a literature review as the study methodology to answer the research question of: "Does telemedicine have effect on self-management of type 2 diabetics?". The development of the research question follows the PICO (population, intervention, comparison, and outcome) guideline to generate a specific research question and to ensure consistency among the selected studies. In this reviwe, the PICO guideline was formulated as: $\mathrm{P}$ : type 2 diabetic patients, I: telemedicine, $\mathrm{C}$ : control group and $\mathrm{O}$ : self-management

\section{Search Strategy}

The keywords used were Telemedicine AND Diabetes type 2 (Adult AND Elderly) NOT Kids. This study used Pubmed electronic database for article search.

\section{Selection Criteria}

The inclusion criteria for this review were studies published from 2015-2020 in English-language, used random control trial design, its population aged $>18$ years, had $\mathrm{HbA} 1 \mathrm{c}$ outcome, and used telemedicine. The exclusion criterion of this review was studies that compared telemedicine with other applications. A total of 11 studies were included in the review.

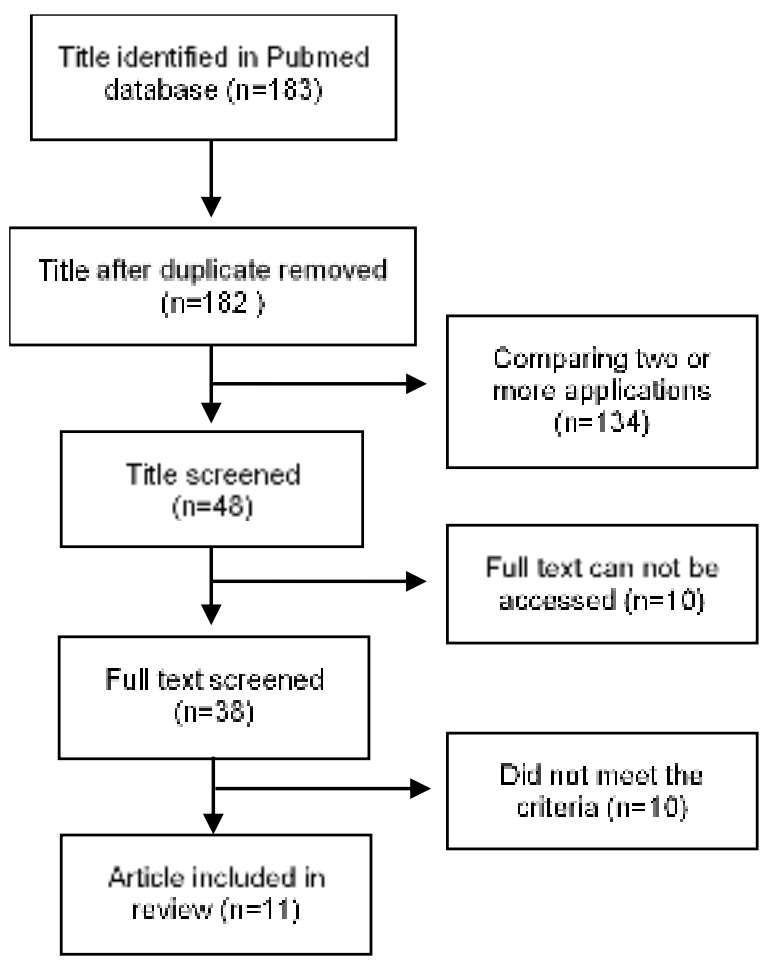

Figure 1. Article selection process

\section{RESULT}

Based on the inclusion and exclusion criteria, it was 11 articles published in the last five years (2015-2020) and these were included in the review. Table 1. show the data extraction of the articles. 


\section{Table 1. Summary of studies}

\section{No. Title (Author)}

1. "Telemedicine-Assisted Self-

Management Program for Type 2

Diabetes Patients"

(Von Storch et al., 2019)

2. "Mobile Phone-Based Telemedicine Practice in Older Chinese Patients with Type 2 Diabetes Mellitus: Randomized Controlled Trial"

(Sun et al., 2019)

3. "Impact of ENHANCED (diEtitiaNs Helping pAtieNts CarE for Diabetes) Telemedicine Randomized Controlled Trial on Diabetes Optimal Care Outcomes in Patients with Type 2 Diabetes"

(Benson et al., 2019)

4. "Smart Care Based on

Telemonitoring and Telemedicine for Type 2 Diabetes Care: Multi-center Randomized Controlled Trial"

(Jeong et al., 2018)

5. "Randomised-Controlled Trial of a Web-Based Dietary Intervention for Patients with Type 2 Diabetes: Changes in Health Cognitions and Glycemic Control"

(Ramadas et al., 2018)

\section{Methods}

This research used a randomized prospective study. There was an intervention group $(n=60)$ and a control group $(n=55)$. The intervention group received a glucometer, a tablet computer and a step counter. They also received coaching by phone for better motivation and diabetes self-management in daily life. Meanwhile, the control group was provided the routine care, without additional treatment. The study evaluated the outcomes of the diabetes lifestyle program after 3 months.

This research used a randomized controlled trial design. There were 91 respondents divided into an intervention group $(n=44)$ and a control group $(n=47)$. The intervention group received a glucometer with data system and advice regarding diet, medication, and exercise via the mHealth telemedicine system. Meanwhile, the control group received usual care without additional treatment. Patients in both groups were monitored at regular 3-month intervals. This research used a randomized controlled study. There was an intervention group $(n=54)$ and a control group $(n=50)$. The intervention group received a sphygmomanometer and a glucometer for self-monitoring and statin while the control group received the regular visit to primary health care. The study examined the results after 12 months.

A prospective 24-week study with a randomized controlled trial on 338 respondents with type 2 diabetes: in the control group there were 113 respondents, in the telemedicine group 112 respondents and in the telemonitoring group 113 respondents. The control group received regular visits from primary healthcare. Both telemonitoring and telemedicine groups received the service that included remote glucose monitoring with programmed decision support, but the former used text and the later used video conferencing with an endrocinologist. The study examined the result after 24 weeks.

This research used a randomized controlled study. The intervention group $(n=62)$ was provided an intensive dietary intervention via web for 6 months. Meanwhile, the control group $(n=66)$ received the standard treatment, which was to visit health services.
Results

There was a decrease in $\mathrm{HbA1c}$ in the intervention group $(\mathrm{M} \pm$ $\mathrm{SD}, 7 \pm 0.96$ compared to the control group $6.89 \pm 1.01)$. There are significant Body Mass Index (BMI) differences in both groups $(p=0.022)$. There were significant results in the intervention group $(\mathrm{p}=0.001)$. Telemedicine can help selfmanagement in people with type 2 diabetes. There was a decrease in $\mathrm{HbA} 1 \mathrm{c}$ in the intervention group.

There was a $\mathrm{HbA1c}$ decrease in the intervention group according to the initial examination with a mean of $7.88 \%$ to $6.97 \%$ at the third month of examination which decreased to $6.84 \%$ at the sixth month of examination. It can be concluded that telemedicine is effective in helping elderly people with type 2 diabetes.

Significant results were found to changes in diet in the intervention group for fruit consumption $(p=0.0011)$ and whole grains $(p=0.0005)$. There was a change in adherence in the intervention group with a $p$ value $=0.014$. The increased measurement of diabetes in the optimal care outcomes in the intervention group and the control group was 3.7 and 3.2 respectively $(p=0.017)$.

The decrease in $\mathrm{HbA} 1 \mathrm{c}$ for 24 weeks in the control group and the telemonitoring group were $0.66 \% \pm 1.03 \%$ vs $0.66 \% \pm$ $1.09 \%$. Meanwhile, in the telemedicine group, the decrease was $0.81 \% \pm 1.05 \%$. All groups have a $p$ value $=0.0001$

Both groups experienced improvement in the Dietary Knowledge, Attitude and Behaviour (DKAB) score with margin post-intervention $(11.1 \pm 0.9$ vs $6.5 \pm 9.4, p<0.001)$ and followup $(19.8 \pm 1.1$ vs. $7.6 \pm 0.7, p<0.001)$. There was no significant difference in the Dietary Stages of Change (DSOC) score and glycemic control, DSOC score in the intervention group (199.7 \pm 18.2 vs $193.3 \pm 14.6, p=0.046)$, fasting blood glucose (FBG) (7.9 


\begin{tabular}{|c|c|c|c|}
\hline No. & Title (Author) & Methods & Results \\
\hline & & & $\begin{array}{l} \pm 2.5 \mathrm{mmol} / \mathrm{L} \text { vs } 8.9 \pm 3.9 \mathrm{mmol} / \mathrm{L}, \mathrm{p}=0.015) \text { and } \mathrm{HbA} 1 \mathrm{c}(8.5 \pm \\
1.8 \% \text { vs. } 9.1 \pm 2.0 \%, \mathrm{p}=0.004) .\end{array}$ \\
\hline 6. & $\begin{array}{l}\text { "Telemonitoring in Fasting Individuals } \\
\text { with Type } 2 \text { Diabetes Mellitus During } \\
\text { Ramadan: A Prospective, } \\
\text { Randomised Controlled Study" } \\
\text { (Lee, Wong, Tan, Nasir \& Lee, 2017). }\end{array}$ & $\begin{array}{l}\text { This research used a cluster randomized controlled study. The } \\
\text { control group }(n=40) \text { received the standard usual care. Meanwhile, } \\
\text { the telemonitoring group ( } n=45) \text { did self-measurement and } \\
\text { transmission of blood glucose results to the website for evaluation } \\
\text { with feedback from the manager. This research was conducted for } 3 \\
\text { months. }\end{array}$ & $\begin{array}{l}\text { The intervention group experienced lower hypoglycemic } \\
\text { symptoms than the control group at fasting [Odds ratio (OR): } \\
0.186,95 \% \text { confidence interval: } 0.04-0.936 ; p=0.04)] \text {. There } \\
\text { was an HbA1c decrease in the intervention group from } 8.79 \% \text { to } \\
8.55 \% \text { compared to the control group }(p<0.01) \text {. The } \\
\text { improvement in quality of life did not reach significance }(p=0.06) \text {. }\end{array}$ \\
\hline 7. & $\begin{array}{l}\text { "Randomized Controlled Trial of } \\
\text { Technology-Assisted Case } \\
\text { Management in Low Income Adults } \\
\text { with Type } 2 \text { Diabetes" } \\
\text { (Egede, Williams, Voronca, Knapp \& } \\
\text { Fernandes, 2017) }\end{array}$ & $\begin{array}{l}\text { This research used a randomized controlled study. There was an } \\
\text { intervention group }(n=44) \text { and control group }(n=41) \text {. The intervention } \\
\text { group regularly sent blood glucose and blood pressure results with a } \\
\text { device (telehealth) and every } 2 \text { weeks the nurse manager titrated } \\
\text { the medication under the supervision of the internist and the } \\
\text { endocrinologist. This research was conducted for } 6 \text { months and the } \\
\text { examination was at months } 3 \text { and } 6 \text {. }\end{array}$ & $\begin{array}{l}\text { There was a decrease in } \mathrm{HbA1c} \text { in the intervention group } \\
\text { compared to the control group }(-0.99, \mathrm{p}=0.024) \text {. }\end{array}$ \\
\hline 8. & $\begin{array}{l}\text { "Efficacy of the Telemedical Lifestyle } \\
\text { intervention Program TeLiPro in } \\
\text { Advanced Stages of Type } 2 \text { Diabetes: } \\
\text { A Randomized Controlled Trial" } \\
\text { (Kempf et al., 2017) }\end{array}$ & $\begin{array}{l}\text { This research used a randomized controlled study. There were the } \\
\text { intervention group }(n=102) \text { which used TeliPro and the control group } \\
(n=100) \text {, which did not use TeliPro and received body weight } \\
\text { measurements, steps count and usual care. This research was } \\
\text { conducted over } 52 \text { weeks and examined at weeks } 26 \text { and } 52 \text {. }\end{array}$ & $\begin{array}{l}\text { There was a more significant change in } \mathrm{HbA1c} \text { in the } \\
\text { intervention group compared to the control group }(p<0.0001) \text {. }\end{array}$ \\
\hline 9. & $\begin{array}{l}\text { "Effects of Telemonitoring on } \\
\text { Glycaemic Control and Healthcare } \\
\text { Costs in Type } 2 \text { Diabetes: A } \\
\text { Randomised Controlled Trial" } \\
\text { (Warren, Carlisle, Mihala \& Scuffham, } \\
2017 \text { ) }\end{array}$ & $\begin{array}{l}\text { This research used a prospective randomized controlled trial. There } \\
\text { was an intervention group ( } n=63 \text { ) and a control group ( } n=63) \text {. The } \\
\text { intervention group was provided an additional diabetes care from the } \\
\text { health officer via a home monitor that described clinical indicators. } \\
\text { Data collection included the quality of life and biomedical measures } \\
\text { and also healthcare (GP, outpatient and inpatient) cost. This } \\
\text { research was conducted for } 3 \text { months. }\end{array}$ & $\begin{array}{l}\text { There were changes at baseline and } 6 \text { months later }(p=0.004) \text {. } \\
\text { The intervention group experienced a decrease from } 8.4 \% \text { to } \\
7.5 \% \text { compared to the control group from } 8.1 \% \text { to } 8.1 \% \text { (no } \\
\text { change). Health care costs in the intervention group were lower } \\
\text { by an average of } \$ 3781 \quad(p=0.001) \text { compared to the control } \\
\text { group of } \$ 4662 \text {. }\end{array}$ \\
\hline 10. & $\begin{array}{l}\text { "Telemonitoring of Type } 2 \text { Diabetes } \\
\text { Mellitus in Italy" } \\
\text { (Dario et al., 2017) }\end{array}$ & $\begin{array}{l}\text { This research used a randomized controlled study. There was the } \\
\text { intervention group }(n=208) \text { which used telemonitoring and the } \\
\text { control group ( } n=91) \text { who were without telemonitoring and received } \\
\text { the usual care. The intervention group sent blood sugar data to } \\
\text { doctors for } 12 \text { months. }\end{array}$ & $\begin{array}{l}\text { There was no increased in the health related quality of life } \\
\text { (HRQoL). This study did not find significant changes in } \mathrm{HbA} 1 \mathrm{c} \text { in } \\
\text { either group. But in the intervention group, there was a reduction } \\
\text { in visits to hospital and hospitalizations }(\mathrm{p}<0.0001 \text { and } \mathrm{p}=0.02) \text {. }\end{array}$ \\
\hline 11. & $\begin{array}{l}\text { "Diabetes Telemonitoring Reduces } \\
\text { the Risk of Hypoglycaemia During } \\
\text { Ramadan: A Pilot Randomized } \\
\text { Controlled Study" } \\
\text { (Lee et al., 2015) }\end{array}$ & $\begin{array}{l}\text { This research used a randomized controlled study. There were the } \\
\text { intervention group }(n=18) \text { which used telemonitoring and the control } \\
\text { group }(n=19) \text { which did not receive telemonitoring and only received } \\
\text { the usual care. The telemonitoring group was provided goal-setting } \\
\text { and individualized feedback. This research was conducted for } 5 \\
\text { weeks (it began before Ramadhan and was carried out during } \\
\text { Ramadhan). }\end{array}$ & $\begin{array}{l}\text { This study did not get the difference in } \mathrm{HbA1c} \text { in the control } \\
\text { group and the intervention group. }\end{array}$ \\
\hline
\end{tabular}




\section{DISCUSSION}

Result showed that the majority of respondents were men with an average age of 50-73 years. Sherman and Williams (2018) conducted a study to find out the perspective of men with a mean age of 55-70 years regarding type 2 diabetes self-management. This qualitative study found that most men in their middle age fear that they will not be able to carry out diabetes self-management such as controlling blood sugar and checking blood sugar regularly. Other reasons are fear of needles and dependence on insulin for life. According to Hawkins, Mitchell, Piatt, and Ellis's (2018) research, fear is a contributing factor to self-management in elderly men with type 2 diabetes.

Telemedicine is an intervention, which is able to overcome communication barriers between healthcare workers and people with type 2 diabetes. Almost all journals stated that telemedicine can help to improve self-management in diabetics. Warren, Carlisle, Mihala and Scuffham (2018) stated that telemedicine is an alternative intervention, which could involve a video conference with doctors and electronic communication about the care plan as well as information and self-management directions for people with type 2 diabetes. This statement is supported by Vadheim, Patch, Brokaw, Carpenedo, Butcher, Helgerson, \& Harwell (2017) who said that video conferences can make better interventions because patients get directions directly. The result obtained was that such a video can increase selfmanagement of people with type 2 diabetes.

Self-management is the ability to manage chronic diseases by the patient themselves (Borhaninejad et al., 2017). Sufferers need knowledge, skill and ability regarding illness, medication and monitoring of blood sugar, diet and physical activity. Almost all journals showed a significant decrease in $\mathrm{HbA1c}$ on the group intervention compared to the control group. $\mathrm{HbA1c}$ is an established marker to monitor diabetic status (Bikramjit, Raveender, and Sudipta, 2017). Glucose control is important for diabetics but $\mathrm{HbA} 1 \mathrm{c}$ is the benchmark for diabetes management. $\mathrm{HbA} 1 \mathrm{c}$ is the part of red blood cells that have a life span of 120 days and are measured every 1-3 months. This finding is supported by 11 journals that have been analyzed. The ideal study duration is 12 weeks or 3 months so that it can describe the changes in $\mathrm{HbA1c}$ in the intervention group and the control group.

The secondary outcome in this review is diet changes in people with type 2 diabetes. The intervention group experienced diet changes, namely consuming fruit and whole grains compared to the control group. Li, Fan, Zhang, Hou and Tang (2014) stated that fruits and vegetables are able to increase insulin sensitivity and produce insulin. Fruits and vegetables have lots of fiber and are low in calories, so sufferers may easily feel full and can reduce high-calorie food intake.

Telemedicine is able to upgrade knowledge, skills and the ability to control blood sugar. According to Jeong et al. (2018), telemedicine using video conferences and text messages can increase knowledge, skill and ability to control the patient's blood sugar. Consultation with health professionals via video conferences is effective and produces better outcomes than without video conferences. Although telemedicine can improve management, people with type 2 diabetes who live in rural areas still have to visit primary health services (Warren et al., 2018). Visiting primary health services is one of the suggestions by health professionals for patients to check their general condition and/or HbA1c.
However, four studies revealed that there were not significant findings in the $\mathrm{HbA} 1 \mathrm{c}$ reduction on the intervention and control group. The first obstacle is due to rural areas. This opinion is strengthened by Purnell et al. (2016) who stated that rural areas mean that it was more difficult for patients to get optimal primary health services. A study by Benson et al. (2019) demonstrated that telemedicine can improve glycemic control of people with type 2 diabetes in the countryside. Telemedicine is a health media service that connects medical personnel to patients. The obstacle that the researcher found was the telemedicine access - that is some clients did not get any news due to no data entered into the server.

The next obstacle is a less specific population. Lee et al. (2015) in their study revealed that 2 weeks is insufficient time to get respondents in a specific manner. The limitation of this study is that it is unable to compare $\mathrm{HbA} 1 \mathrm{c}$ differences. HbA1c examination is around 1-3 months because the lifespan of red blood cells is approximately 120 days. This study was conducted for 5 weeks and there was insufficient time to describe $\mathrm{HbA} 1 \mathrm{c}$ differences.

The third obstacle is web page-based telemedicine. Ramadas et al. (2018) in their study explained that the limitation of the study experienced was that there was no significant change in $\mathrm{HbA} 1 \mathrm{c}$ in the intervention and control groups. Rasekaba, Lim, Blackberry, Gray and Furler (2016) explained that web-based telemedicine intervention was only in addition to usual care and the duration of the consultation was short. Regular care remains the basis for client self-management. The majority of journals, which were analyzed, give different treatment in the intervention and control groups, that is, the intervention group focused on the researchers' plan while the control group focused on the regular care.

The limitation of this review is it does not evaluate which application with the best outcomes. It only reviews the effect of telemedicine on self-management in general.

\section{CONCLUSION AND RECOMMENDATION}

Telemedicine based applications on the smartphone improves self-management among type 2 diabetes patients indicated by the decreased $\mathrm{HbA} 1 \mathrm{c}$, increased glycemic control, change in diet, and increased self-management activity. Telemedicine has a potential to be an alternative during the COVID-19 pandemic. It is recommended that nurses and other health care professionals can use telemedicine as an alternative to improve self-management of type 2 diabetes patient.

\section{REFERENCES}

Benson, G. A., Sidebottom, A., Hayes, J., Miedema, M. D., Boucher, J., Vacquier, M., Sillah, A., Gamam, S., \& VanWormer, J. J. (2019). Impact of ENHANCED (diEtitiaNs Helping pAtieNts CarE for Diabetes) telemedicine randomized controlled trial on diabetes optimal care outcomes in patients with type 2 diabetes. Journal of the Academy of Nutrition and Dietetics, 119(4), 585-598.

Bikramjit, P., Raveender, N. \& Sudipta, P. (2017). The importance of $\mathrm{HbA} 1 \mathrm{C}$ and erythrocyte sedimentation rate as prognostic factors in predicting the outcome of diabetic foot ulcer disease. International Journal of Advances in Medicine, 4(1), 137-142. 
Borhaninejad, V., Iranpour, A., Shati, M., Tahami, A. H., Yousefzadeh, G. \& Fadayevatan, R. (2017). Predictors of self-care among the elderly with diabetes type 2: Using social cognitive theory. Diabetes \& Metabolic Syndrome: Clinical Research \& Reviews, 11(3), 163-166.

Dario, C., Toffanin, R., Calcaterra, F., Saccavini, C., Stafylas, P., Mancin, S. \& Vio, E. (2017). Telemonitoring of type 2 diabetes mellitus in Italy. Telemedicine and e-Health, 23(2), 143-152.

Egede, L. E., Williams, J. S., Voronca, D. C., Knapp, R. G. \& Fernandes, J. K. (2017). Randomized controlled trial of technology-assisted case management in lowincome adults with type 2 diabetes. Diabetes Technology \& Therapeutics, 19(8), 476-482.

Ghosh, A., Arora, B., Gupta, R., Anoop, S. \& Misra, A. (2020). Effects of nationwide lockdown during Covid19 epidemic on lifestyle and other medical issues of patients with type 2 diabetes in North India. Diabetes \& Metabolic Syndrome: Clinical Research \& Reviews, 14(5), 917-920.

Hawkins, J., Mitchell, J., Piatt, G. \& Ellis, D. (2018). Older African American men's perspectives on factors that influence type 2 diabetes self-management and peerled interventions. Geriatrics (Basel, Switzerland), 3(3), 2-10.

International Diabetes Federation. (2019). Diabetes in Western Pacific. Retrieved 2019, from https://www.idf.org/our-network/regionsmembers/western-pacific/members/104-indonesia

Jeong, J. Y., Jeon, J. H., Bae, K. H., Choi, Y. K., Park, K G., Kim, J. G., . . . Lee, I. K. (2018). Smart care based on telemonitoring and telemedicine for type 2 diabetes care: Multi-center randomized controlled trial. Telemedicine and E-Health, 24(8), 604-613.

Kempf, K., Altpeter, B., Berger, J., Reuß, O., Fuchs, M., Schneider, M., Gärtner, B., Niedermeier, K. \& Martin, S. (2017). Efficacy of the telemedical lifestyle intervention program TeLiPro in advanced stages of type 2 diabetes: A randomized controlled trial. Diabetes Care, 40(7), 863-871.

Lee, J. Y., Lee, S.W. H., Nasir, N. H., How, S., Tan, C. S. S. \& Wong, C. P. (2015). Diabetes telemonitoring reduces the risk of hypoglycaemia during Ramadan: A pilot randomized controlled study. Diabetic Medicine, 32(12), 1658-1661.

Lee, J.Y., Wong, C.P., Tan, C. S. S., Nasir, N.H. and Lee, S.W.H., (2017). Telemonitoring in fasting individuals with type 2 diabetes mellitus during Ramadan: A prospective, randomised controlled study. Scientific Reports, 7(1), 1-9.
Li, M., Fan, Y., Zhang, X., Hou, W. \& Tang, Z. (2014), Fruit and vegetable intake and risk of type 2 diabetes mellitus: Meta-analysis of prospective cohort studies. BMJ Open, 4(11), 1-9

Malini, H., Yeni, F., Pratiwi, C.A. \& Lenggogeni, D.P., (2020). Associated factors of self-management in type 2 diabetes mellitus at community health center. Jurnal Keperawatan Soedirman, 15(2), 24-30.

Purnell, T. S., Calhoun, E. A., Golden, S. H., Halladay, J. R., Krok-Schoen, J. L., Appelhans, B. M. \& Cooper, L. A. (2016), Achieving health equity: Closing the gaps in health care disparities, interventions, and research. Health Affairs, 35(8), 1410-1415.

Ramadas, A., Chan, C. K. Y., Oldenburg, B., Hussein, Z. \& Quek, K. F. (2018). Randomised controlled trial of a web-based dietary intervention for patients with type 2 diabetes: Changes in health cognitions and glycemic control. BMC Public Health, 18(1), 1-13.

Rasekaba, T.M., Lim, K., Blackberry, I., Gray, K. \& Furler, J. (2016). Telemedicine for Gestational Diabetes Mellitus (TeleGDM): A mixed-method study protocol of effects of a web-based GDM support system on health service utilization, maternal and fetal outcomes, costs, and user experience. JMIR Research Protocols, 5(3), 1-12.

Sherman, L.D. \& Williams, J.S. (2018). Perspectives of fear as a barrier to self-management in Non-Hispanic Black men with type 2 diabetes. Health Education \& Behavior, 45(6), 987-996.

Sun, C., Sun, L., Xi, S., Zhang, H., Wang, H., Feng, Y., . . . Gao, Y. (2019). Mobile phone-based Telemedicine Practice in Older Chinese Patients with Type 2 Diabetes Mellitus: Randomized Controlled Trial. JMIR mHealth and uHealth, 7(1), 1-9.

Vadheim, L.M., Patch, K., Brokaw, S.M., Carpenedo, D., Butcher, M.K., Helgerson, S.D. \& Harwell, T.S. (2017). Telehealth delivery of the diabetes prevention program to rural communities. Translational Behavioral Medicine, 7(2), 286-291.

Von Storch, K., Graaf, E., Wunderlich, M., Rietz, C., Polidori, M. \& Woopen, C. (2019). Telemedicineassisted self-management program for type 2 diabetes patients. Diabetes Technology \& Therapeutics, 21(9), 514-521.

Warren, R., Carlisle, K., Mihala, G. \& Scuffham, P. A. (2018). Effects of telemonitoring on glycaemic control and healthcare costs in type 2 diabetes: A randomised controlled trial. Journal of Telemedicine and Telecare, 24(9), 586-595.

World Health Organization. (2020). WHO Coronavirus (COVID-19) dashboard. Retrieved from https://covid19.who.int/ 